\title{
Modern Linguistic Research in Regional and Cross-Cultural Context: Analytical Review for the Linguistic Edition of the Journal of Siberian Federal University
}

\author{
Iuliila I. Detinko and Liudmila V. Kulikova* \\ Siberian Federal University \\ Krasnoyarsk, Russian Federation
}

Received 22.03.2021, received in revised form 05.04.2021, accepted 12.04.2021

\begin{abstract}
Modern linguistic research is characterized by a quick reaction to the world events, a response to the challenges of our time in various spheres of public life, a tendency to find an explanation for new linguistic and social phenomena through the cultural and historical perspective. On the one hand, this trend stimulates interest in regional studies, whose topical issues are related to translation of values in constructing the image of the region, revealing of cultural information on the material of local toponyms, solving the problems of contextually determined bilingualism and language policy in the regions with indigenous population. On the other hand, interest in the study of other cultures does not decline and still has vast scientific potential due to the possibility of a more detailed immersion in the peculiarities of cross-cultural communication and the use of new methodological tools for its study. Modern technologies make it possible to use the resources of the Web networks for solving research problems, thereby expanding and enriching the spheres of discourse interaction.
\end{abstract}

Keywords: regional linguistics, cross-cultural context, discursive practices of global media.

Research area: linguistics.

Citation: Detinko, Iu.I., Kulikova, L.V. (2021). Modern linguistic research in regional and cross-cultural context: analytical review for the linguistic edition of the Journal of Siberian Federal University. J. Sib. Fed. Univ. Humanit. Soc. Sci., 14(4), 454-458. DOI: 10.17516/1997-1370-0744.

\footnotetext{
(C) Siberian Federal University. All rights reserved

* Corresponding author E-mail address: julia_detinko@mail.ru, kulikova_1@list.ru ORCID: 0000-0001-8254-8085 (Detinko); 0000-0002-1622-8304 (Kulikova)
} 
в региональном и кросс-культурном контексте: аналитический обзор к лингвистическому выпуску
«Журнала Сибирского федерального университета.
Гуманитарные науки»

\author{
Ю.И. Детинко, Л.В. Куликова \\ Сибирский федеральный университет \\ Российская Федерачия, Красноярск
}

\begin{abstract}
Аннотация. Особенностью современных лингвистических исследований является быстрое реагирование на происходящие в мире события, отклик на вызовы современности в различных сферах общественной жизни, стремление найти объяснение новым языковым и социальным явлениям через призму культурной и исторической перспективы. С одной стороны, такая тенденция порождает особый интерес к региональным исследованиям, в которых на первое место выходят актуальные вопросы трансляции ценностных ориентиров при формировании образа региона, выявления лингвокультурной информации на материале местных топонимов, а также проблематика контекстуально опосредованного двуязычия и языковой политики в регионах с коренным населением. С другой стороны, не угасает интерес к изучению иных культур, что имеет обширный научный потенциал из-за возможности более детального погружения в особенности кросс-культурной коммуникации и применения нового методологического инструментария для ее исследования. Современные технологии позволяют задействовать ресурсы глобальных веб-сетей для решения исследовательских задач, тем самым расширяя и обогащая сферы дискурсивного взаимодействия.
\end{abstract}

Ключевые слова: региональная лингвистика, кросс-культурный контекст, дискурсивные практики глобальных медиа.

Научная специальность: 10.02.00 - языкознание.

The current issue of the Journal of Siberian Federal University. Humanities and Social Sciences addresses the specifics of ethnographic and cross-cultural phenomena with an attempt to look at languages and cultures from various angles: scientific communication, different aspects of political discourse, cultural and historical contexts, media coverage. The ethnocultural studies appealing to regional component as a source of ethnographic information help to reveal the culturally essential knowledge hidden in toponyms, ethnonyms, semantic and axiological meanings. In this respect it is interesting to look at the myths about the origin of some peoples and appearance of their names. The researchers whose works are presented in this issue also dwell upon the problems of language policy in Siberian regions and heroic epic texts in the Yakut and Tyvan languages.

The vast studies of culture prove that "contemporary theories of culture emphasize the complexity, fluidity and multiplicity of cultures with national conceptions of culture forming just one of many cultural groupings individuals identify with" (Baker, 2015: 133). It affects people's vision of the world, which becomes clearly noticeable when it comes to cross-cultural communication. Interacting with other cultures via foreign texts or media resources, people perceive a certain picture of the world different from their own due to distinctions of mentalities and national natures; 
influence of cultural stereotypes; discrepancy of cultural and language regulations and other factors (Rtischeva, 2018: 129). It is obvious that one of the benefits of cross-cultural communication research is "its ability to capture the breadth of communicative styles that exist globally" (Ghanem, Speicher, 2017: 168). That is why the variety of studies embracing culture-related aspects is of great importance. The significance of studies is also determined by the innovative nature or methodology of the conducted research or appeal to topical issues. Thus, the authors dwell upon the new approach to Chinese cultural discourse, employ the method of semantic experiment to study modality of Chinese dialogical texts, introduce the idea of discourse-world of Brexit in the British media, examine the nominations in texts about coronavirus in the news media of Europe and Asia.

The issue opens with the block of regional research articles devoted to the languages of the people from Siberia, Khakassia, Altai, Yakutia and Tuva.

The first article "Image of Siberia and Siberians in English: Linguistic Interpretation of Axiological Meanings" by Ekaterina S. Muchkina and Marina A. Bitner (Krasnoyarsk) focuses on the representation of the regional culture of Siberia in the English language. Through the analysis of the axiological meanings conveyed by the word "Siberia" and its derivative "Siberian" the authors identify a few peculiar characteristics inherent to the stereotypical image of Siberia in English. The revealed stereotypes about the region and its residents provide a basis for developing a strategy of promoting this region with a rich cultural history and tradition.

The next article "Contextualized Bilingualism in the Republics of Southern Siberia" by Tamara G. Borgoiakova and Aurika V. Guseinova (Abakan) raises the issue of vertical bilingualism among the indigenous peoples of Khakassia, Tuva and Altai. The authors claim that the development of bilingualism in the Republics of Southern Siberia is influenced by the social context of languages functioning and language attitudes. Although bilingualism is considered a norm for these Siberian peo- ples, their language behavior is determined by a strong instrumental and integrative motivation for using Russian as a language of social advancement. Finally, the authors mention the factors affecting the development of additive type of bilingualism in the current conditions.

The block of regional studies is continued by the "Review of Toponymic Studies of Altai and Siberia in the Anthropocentric Paradigm" by Svetlana P. Vasil'eva (Krasnoyarsk) and Lidia M. Dmitrieva (Barnaul). The article focuses on the regional toponymy research basing on the anthropocentrism principles which make it possible to reveal the deeper structures of the knowledge encompassed in the toponymicon. The authors claim that toponymy is a valuable source of ethnocultural information that may be extracted within the anthropocentric paradigm through cognitive modelling and linguistic and cultural interpretation including the analysis of "toponymic contexts", analysis of discourse, analysis of associations and other methods.

The heroic epic texts in the Yakut and Tyvan languages are studied in the article "On the Functional Features of Image-Forming Verbs in Yakut and Tyvan Epic Texts: Comparative Analysis" by Liliya N. Gerasimova (Yakutsk). As the research material the author takes the Yakut olonkho "Dyyray Bogatyr, The Son of the Horse" by I.I. Burnashev and the Tyvan heroic epic "Khunan Khara" by Chanchy-Hoo Oorzhak and identifies the semantic equivalents and functional features of the image-forming verbs in the epic texts. The analysis of the verbs is performed in the aspects of their quantitative representativeness in both languages, storytelling peculiarities, structure of the image-forming verb stems.

The article "Ethnogonic Texts in the Indo-European Tradition" by Sergei G. Proskurin and Anna V. Proskurina (Novosibirsk) reveals the thematic contours of Indo-European texts containing ethnogonic myths about the origin of peoples. The authors examine the origin of the name of the Ingaevon tribe, basing on the segment of the Anglo-Saxon runic series that correlates with Tacitus's description of this tribe origin and makes it possible to reconstruct the parameters 
of the ethnically derived text thus explaining the choice of the sequence of the runes of the Anglo-Saxon futhork. The article also dwells upon the German influence on the choice of the ethnonym Rus and the origin of the name of Italy.

Deep knowledge of other cultures is an important condition of successful cross-cultural communication. Interaction with China is becoming a growing trend nowadays. That is why the modern view on Chinese cultural discourse and the peculiarities of functioning the final modal particle 啊 in Chinese dialogical text are of special interest in this issue.

The article "A New Approach to Chinese Discourse: Cultural Context" by Irina G. Nagibina and Liudmila V. Kulikova (Krasnoyarsk) attempts to present a version of Chinese cultural discourse studies with special reference to discursive practice in contemporary China. The Chinese cultural psychological constituents are presented in terms of cultural and communicative vectors and their implementation variants (moduses). The authors reveal culturally determined communicative and discursive conventions of the Chinese social interaction with special emphasis made on such phenomena as harmony, face, authority-oriented emotions, respect for authority, politeness and relations, meaning beyond language, dialectical thinking, the collective memory and self-concept related emotion, patriotism.

In the article "The Function of the Final Modal Particle 啊 in Chinese Dialogical Text: the Method of a Semantic Experiment" Sofya A. Simatova and Vladimir A. Kurdyumov (Moscow) use the procedure of the semantic experiment that involves the native speakers of Chinese and gives the tools for statistical data processing which makes the research more objective. In the experiment, the respondents were asked to evaluate the possibility of excluding the final modal particle 啊 from the declarative, imperative, usual interrogative sentences and rhetorical questions. As a result, the authors reveal three key functions of the studied particle and explain the cases when the respondents feel a certain difference between the sentences with and without the particle 啊 and when this difference is not noticeable.
This issue looks at diverse spheres of communicative interaction which can have a considerable influence on people's mutual understanding and effective collaboration. The following work addresses some aspects of scientific discourse. In the article "Categoricalness in Scientific Discourse" by Nadezhda N. Panchenko (Volgograd) and Yana A. Volkova (Moscow), the authors explore the distribution and function of the communicative category of categoricalness in scientific discourse and identify possible ways of reducing or avoiding it. It is claimed that categoricalness as a category of communicative interaction is directly related to the categories of reliability, emotionality, persuasiveness and authoritativeness. Basing on the analysis of the texts of scientific reviews and oral scientific discussions and disputes the authors give the main features of Russian scientific communication and emphasize that communicative category of categoricalness should be studied in detail with subsequent development of practical recommendations for researchers on the ethics of working with scientific text or holding scientific debates.

Nowadays we clearly understand the role of media in our society. The modern world changes rapidly providing the researchers with new realia which need to be analyzed. Being interactive, the global network "contributes to communicative processes in the wider society" (Matheson, 2005: 167). We take advantage of the Web resources and have access to the updated information straight from the source. The final block of this issue is devoted to the study of media determined discursive practices in different spheres.

The article "Images of Slavs in Discourse-World of Brexit" by Svetlana L. Kushneruk (Chelyabinsk) aims at examining the dominant images of the Slavic national groups (Western, Eastern, Southern) in the British media in the context of Britain's withdrawal. The author implements cognitive-discursive analysis taking into account communicative, cognitive and social factors in analyzing media discourse and introduces the term "discourse-world of Brexit" to denote a complex discourse-related conceptual structure serving 
as a background, against which national images stand out. It is claimed that images of the Slavs are organized by frames which are systematized in the article.

Considering the challenges of today, COVID-19 is becoming a more and more topical issue of studies, including linguistics. Irina S. Karabulatova, Margarita D. Lagutkina (Moscow) and Stefania Amiridou (Komotini, Greece) truly mention that today news stories about coronavirus are at the top of the list worldwide. In the article "The Mythologeme "Coronavirus" in the Modern Mass Media News in Europe and Asia" the authors analyze the impact of nominations in the media discourse on the coronavirus on the public consciousness of the people from different ethnolinguo-confessional environments. The authors consider the historical, sociological and psycholinguistic aspects of the use of names in texts about coronavirus, identify the features of the impact of such texts on the readers and determine the target orientation of such texts.

The article "Variability of News Interpretation in Political Discourse (A Case Study of the Internet Materials Covering the 2014 and 2018 Winter Olympic Games)" by Nikolay D. Golev, Lidiya G. Kim and Irina V. Saveleva (Kemerovo) focuses on the analysis of the discourse formed by the ordinary citizens discussing news on the Internet social networks. Such events as the 2014 and 2018 Olympic Games being mediated, stimulate the interpretation activity of the addressees who tend to discuss political background of the sports events and to disclose major problems in society. The authors identify the main vectors of interpretation, including explicit meanings and implicit content of the original non-political text. The implicit intentions of the interpreter are associated with the mechanism of expectation which seems to act as the most important factor of the receptive-interpretative activity.

The aspects of culture include the reference to gender discourse. In the article "Gender Features in Female Political Discourse: The Construction of Hillary Clinton's Political Image" Natal'ia S. Baikalova (Krasnoyarsk) finds out the gender markers that represent a woman-politician. The analysis is performed from two perspectives: the politician's behavior and the media sources coverage of this behavior. Claiming that Hillary Clinton is mostly represented as a masculine politician the author identifies and describes the three images through which the woman-politician is shown in the media.

The articles included in this issue present a variety of modern trends in regional linguistics as well as cultural and cross-cultural studies. We believe that all of them answer the challenges of time and contribute to the field of communication research in its different directions and spheres.

\section{References}

Baker, W. (2015). Research into Practice: Cultural and intercultural awareness. In Language Teaching, 48(1), 130-141. DOI: 10.1017/S0261444814000287

Ghanem, S., Speicher, B. (2017). Comparative Persuasive Styles in Arabic and English: A Study of the United Nations General Assembly Debate Speeches. In Journal of International and Intercultural Communication, 10(2), 168-182. DOI: 10.1080/17513057.2016.1219759

Matheson, D. (2005). Media Discourses: Analyzing Media Texts. Maidenhead, Open University Press, 206 p.

Rtischeva, O.V. (2018). Content of language cultural universal in cross-cultural communication. In J. Sib. Fed. Univ. Humanit. Soc. Sci., 12(1), 128-136. DOI: 10.17516/1997- 1370-0333. 